Phenomenology \& Practice, Volume 6 (2012), No. 2, pp. 153-179.

\title{
Coming To Craft and Coming Of Age: Teaching Advanced Placement English In The Classroom-Workshop
}

\author{
Suzanne Borenzweig, Northwest High School in Germantown, Maryland (Montgomery \\ County Public Schools), U.S.A. \\ Email: suzanne_r_borenzweig@mcpsmd.org
}

\begin{abstract}
This article explores the lived experiences of Advanced Placement English teachers in public high school, as the author addresses the question: "What is it like to teach Advanced Placement English while caught in the tension between teaching and testing?" The phenomenological text constructed from conversations and written reflections with six Advanced Placement teachers brings forth aspects of the experience of dwelling aright in the Zone of Between in AP English teaching: between teaching and testing, high school and college, and childhood and adulthood. The teachers use the exam as a foundation for courage and encouragement, confidence and passion building, and creative ways-of-being with students. The study suggests a need for Advanced Placement teachers to participate in the development of curriculum, to retain the autonomy to teach from the self, and to be trusted to provide students with meaningful experiences in the art and craft of literature study. The article also reveals the importance of widening the narrow definition of student achievement to include more than test scores.
\end{abstract}

\section{Appreciating “This Stuff”}

It is one week before the Advanced Placement (AP) Literature exam. All class activities and concerns now focus on our last-minute preparations for the College Board test on Monday. We are reviewing a multiple-choice practice on the poem "A Whippoorwill in the Woods" by Amy Clampitt (College Board, 1995). It's a lengthy poem, eleven stanzas, and my student Molly asks if she should read the poem before she begins to answer the multiple choice questions that follow. I let my forehead fall to my desk with a dramatic thud: "Have I taught you nothing?" Student Julia comes to Molly's defense, "That's what we learned in SAT Prep. You don't need to read the whole passage - there's no time." "How can you possibly appreciate the poem," I ask, "if you don't read it?" Molly responds in earnest, "Are we really supposed to appreciate this stuff?"

This stuff? A school year of some of the most wonderful poems, plays, and novels reduced to adolescent vernacular as "this stuff." I feign horror and disbelief, but inside I feel torn about what to tell her, and disappointed in what she may have learned from me in our class. I assure Molly and her classmates that they do indeed have time to read and appreciate the literature on which they are being tested. But during my commute home 


\section{Borenzweig}

later, I will mull over this exchange and acknowledge that Molly and Julia may have been right: there is not a whole lot of time to appreciate literature during a grueling three-hour high-stakes exam. Have I been complicit in their understanding of literature-as-testfodder and nothing more? Their parents pay $\$ 87.00$ per AP test and want to see the big pay off: early college credit at bargain basement prices. Their children are, for the most part, well behaved and eager-to-please; they want to score-off-the-charts, across-theboard. I admit that sometimes I teach to the test. And I have one more confession-I don't teach to the test nearly as often as I should.

AP English teachers are caught in the tension between teaching a rich and engaging college-level introductory English course to high school students, and preparing those same students to earn a score of 4 or 5 on a three-hour standardized test in early May. Some might argue that the two are not mutually exclusive; that the skills needed to do well on the test are the very skills one needs to study and understand literature. But Molly's question and Julia's defense attest to the effect of such testing on our teaching and learning. Molly and Julia are top students who would only take short cuts to improve their performance. Swiftness in reading, thinking, and writing is tantamount to doing well on the AP Lit exam. Both Molly and Julia are depending on me to help them. What is it like to prepare students for a standardized test while simultaneously trying to engage them in meaningful experiences of literature and writing?

Although much has been written about how to prepare the students for the exams, including how to structure the course and how to choose texts, little exists on what it is like for teachers to teach Advanced Placement English. For much of the school year, the specter of the exam looms like Catherine Earnshaw's ghost outside Lockwood's window during his first slumber party at Wuthering Heights.

These initial musings led me to articulate the essential phenomenological question: What is it like to teach Advanced Placement English in public high school while caught in the tension between teaching and testing? To begin to explore aspects of the tension, I engaged in conversations with six public school teachers about their work in the Advanced Placement English classroom. The teacher-participants-Amanda, Tina, James, Katherine, Amy, and Lisa - also reflected on their practice through a series of shared journal entries.

The phenomenological texts of life as they are lived in the AP classroom helped me "to understand better what is most common, most taken-for-granted, and what concerns us most ordinarily and directly" (van Manen, 2003, p. 19) as teachers and as human science researchers. Drawn in particular to the community of students who have been labeled "advanced" and registered in a course that gives them "placement" in a quasicollegiate life-world that technically is not yet theirs to inhabit as high school students, I relied on phenomenology to illuminate the unique practice of the teachers who, with their students, are dwelling in several seemingly disparate worlds at once: teaching and testing, high school and college, and childhood and adulthood.

The Advanced Placement English teacher "in-dwells between two horizons- the horizon of the curriculum-as-plan as she understands it and the horizon of the curriculumas-lived experiences with her pupils" (Aoki, 2005b, p.161). Although the College Board does not prescribe curriculum per se, the year-end College Board exam for which the students may earn college credits guides an AP teacher's planning and focus. To reconcile the seemingly irreconcilable polarities of testing and teaching, I have come to 
understand "that in-dwelling in the zone between curriculum-as-plan and curriculum-aslived experiences is not so much a matter of overcoming the tensionality but more a matter of dwelling aright within it" (p.163). This "dwelling aright" can be named as the art of being comfortably uncomfortable in the "Zone of Between" (p.163). The teachers approach their tension-filled work as master-craftspeople in the classroom-workshop, passing on to their student-apprentices the art and craft of reading, writing, thinking, and test-taking in the AP English classroom.

\section{Coming to Craft in the Teaching of Advanced Placement English}

Deborah Meier writes in her (2002) book, In Schools We Trust: "Children once learned the arts and crafts of being a grown-up by belonging to a community whose habits and rituals they naturally absorbed" (Meier, 2002, p. 11). Until a century ago, most children did not go to school, but instead learned their way to adulthood by being in the company of adults in small communities, from farms to factories to multigenerational family homes. Fortunately, schools replaced workplaces as more appropriate settings for growing children, but as a result, children tend to spend less time with adults, and more time alone and with peers. The six teachers in my study in-habit classrooms that are reminiscent of the communities of yore to which Meier alludes. Hardly an early twentieth century shoe factory or sheep farm, the AP English classroom is a multigenerational site of process and productivity for both teachers and students.

Through practiced habits and in-grained rituals, the AP English classrooms may resemble medieval workshops; teaching and learning communities where "the arts and crafts of being a grown-up," are being passed on to a generation of young literary apprentices. The high school students engaged in AP English study, for which they may earn up to six college credits if they earn a qualifying score on the College Board exam in May, learn the arts and crafts of alleged college-level literary analysis in the high school setting. The AP English teachers seek to foster a lifelong love of literature and learning with student-apprentices who may be more focused on test scores than on acquiring "the arts and crafts of becoming a grown up." The students are expected to naturally absorb "habits and rituals of being a grown up" in a classroom setting that may be geared toward performing well on a high-stakes high school test, unlike any the students will ever have in college or anywhere else in their adult lives. What is the experience of being inbetween childhood and adulthood - and between art and craft - in the AP English classroom?

The teaching of AP English is the teaching of art; in addition to the art of the literature itself, we study the art of literary analysis, the art of thinking, writing, and speaking about literature, and even the art of standardized test-taking. Richard Sennett posits in his (2008) book The Craftsman: "In terms of practice, there is no art without craft; the idea for a painting is not a painting" (p. 65). In our study, appreciation, and analysis of the art of poetry, fiction, and drama in AP English, we also practice the craft of thinking, writing, and speaking about literature. The practice of art requires the practice of craft. Through our teaching of AP English, our students become our apprentices in the workshop of literary analysis and standardized test-taking.

Though the concept of craft may bring to mind images of the manual labors of carpentry, masonry, and welding, perhaps we can add teaching AP English in public 


\section{Borenzweig}

school as "a way of life" (Sennett, 2008, p. 9) that craftsmanship includes. The teaching of AP English fits this definition of craftsmanship put forth by Sennett:

Craftsmanship names an enduring, basic human impulse, the desire to do a job well for its own sake. Craftsmanship cuts a far wider swath than skilled manual labor; it serves the computer programmer, the doctor, and the artist; parenting improves when it is practiced as a skilled craft, as does citizenship. (p. 9)

Teaching, particularly teaching AP English, names "an enduring, basic human impulse" for the six teacher-participants in this study. Though Sennett does not list teaching as part of the "wider swath" included in the definition of craftsmanship, we can consider his mention of parenting as a "skilled craft" similar to teaching. Van Manen (1991) writes of in loco parentis as a "primary pedagogical responsibility:"

Parenting and teaching derive from the same fundamental experience of pedagogy: the human charge of protecting and teaching the young to live in this world and to take responsibility for themselves, for others, and for the continuance and welfare of the world. (p. 7)

AP English teachers experience "protecting and teaching the young" while simultaneously preparing them for a three-hour College Board exam. We do a job "well for its own sake" while pushing our students to earn high test scores in the AP Englishclassroom workshop.

\section{Home Workshop}

Sennett states, "The workshop is the craftsman's home" (p. 53). He explains the statement's historical background that "in the Middle Ages craftsmen slept, ate, and raised their children in the places where they worked" (p. 53). Fortunately, we AP English teachers in public school get to live in our own homes, apart from school, but our classroom-workshops still become our home-away-from-home, our-second-home, our querencia. Querencia, a Spanish word for which there is no English equivalent, refers to

A place where one feels safe, a place from which one's strength of character is drawn, a place where one feels at home. It comes from the verb querer, which means to desire, to want. (Heard, p. 4, 1995)

Our classrooms are where our passions meet our desires and our wants, and whether they are yet aware or not, our students' desires and wants. I have come to know and to name the AP English classroom as a place of safety, a place of autonomy, a place as comfortable as my own skin, "a place from which [my] strength of character is drawn" (Heard, p. 4, 1995). The strength and the power are borne, in part, from the workshop sites, where we are living-the-tensions, adapting-to-the-tensions, and surviving-thetensions: teaching and testing, pushing and pulling, holding on and letting go.

The term workshop has a variety of connotations in the teaching of English. We may facilitate writing workshops with our students and their papers to help with 
brainstorming, peer-editing, and/or revising; we may have in-class poetry workshops to focus on particular poems, poets, or ways of understanding; we may attend College Board and other training workshops throughout our careers to-gather/to-gether with colleagues, hone our craft, and stay current on the latest pedagogical approaches, or changes to the AP English exams. We don't often, however, think of our physical classrooms as workshops, but in several senses, they are. Heidegger (1953/1996) writes:

The simple conditions of craft contain a reference to the wearer and the user at the same time. The work is cut to his figure; he "is" there as the work emerges... Here the world is encountered in which wearers and users live, a world which is at the same time our world. The work taken care of in each case is not only at hand in the domestic world of the workshop, but rather in the public world. (p. 66)

We dwell in the "domestic world" of the workshop-classroom and the "public world" of the standardized test at the same time in the teaching of AP English. The compound noun work-shop derives from work: "Action involving effort or exertion directed to a definite end, esp. as a means of gaining one's livelihood" and shop, "A house or building where goods are made or prepared for sale and sold" (OED Online, 1989/2008). Indeed, the AP English classroom is where AP teachers gain their livelihood, and earn a paycheck for their labor and toil. But what is the nature of the students' work, both as individual students and in-concert with their AP teachers?

Digging deeper through the dictionary definitions, work also refers to, "The labour done in making something, as distinguished from the material used," as in the difference between labor and parts on a bill from the auto mechanic. What constitutes our labor in AP English? What constitutes our parts? Toward what "definite end" are we directing our work, our labor, and our parts? I re-call Amanda's words, "I don't really look at the test as being their ultimate goal. I tell them that it's a goal, but for me, that's not really my goal for them." If our test scores are not our valued end-products, then what "work" do we produce in the work-shop? What craft are we training our student-apprentices to practice? What "goods" do we make and "sell" in the AP English classroom?

One thing is for certain: we are not selling tests or test scores. A few hours before I arrive at Tina's classroom for our second conversation, one of her students mistakenly thinks he should give her the check for the exam in May. At Tina's school, the business office oversees test registration, and she didn't know that exam fee collection season had begun. Tina related:

So this kid comes up to me today, gives me a check, and says, "Here's for the class." And you just feel kind of cheap. This is not a service; it's not a business deal. That's what it has become with the College Board, and the scores, and the colleges. It seems like the colleges are in cahoots with the College Board, so it just seems like a whole business cycle. I didn't want to be part of that cheap little cycle. It's education. It's supposed to be about the child.

For Tina, the check is a stark reminder of an aspect of her job that troubles, even angers, her. Though traditional workshops were places of commerce that also trained apprentices, 
as a high school teacher, Tina wants no part of the College Board's "negotiated business deal." She asserts that if she is "in cahoots" with anyone, she is "in cahoots" with her students and what she knows are their best interests as they prepare for college and for life.

\section{Wood Shop}

Heidegger's (1993) example of the “cabinetmaker's apprentice” (p. 379) further illuminates the experience of learning and teaching in the classroom-workshop, without the exchange of money:

[The apprentice's] learning is not mere practice, to gain facility in the use of tools...If he is to become a true cabinetmaker, he makes himself answer and respond above all to the different kinds of wood and to the shapes slumbering within wood-to wood as it enters into man's dwelling with all the hidden riches of its essence. (p. 379)

Teachers have the experience of answering, responding-to, and shaping "different kinds of wood" in the AP English workshop. We awaken the slumbering shapes within, as we teach our students to awaken slumbering shape. From Amy Clampitt's poem, "A Whippoorwill in the Woods," to Robert Frost's "Stopping By Woods on a Snowy Evening," to all of the literature we study, with or without the word wood in the title, we are cabinetmakers with apprentices, master-woodworkers in the AP English classroomworkshop, responding to the literature's "hidden riches of its essence" (Heidegger, 1993, p. 379) in "wood working" with our students.

Shop has a specific North American connotation, "A school room equipped for teaching the arts of the workshop," (OED Online, 1989/2008) formerly known as "shop class"; better known as "technology education" in today's parlance. Despite my use of Heidegger's cabinetmaker's apprentice as an example, the concept of the AP English classroom as a workshop is not readily analogous to "shop class" or "vo-tech," those classes that teach "trades" ranging from auto body repair to pedicures to phlebotomy. Yet, the AP English classroom may be understood as a production site, a place where goods are produced or elaborated, where student-apprentices "labor-at" and learn the literary and standardized test-taking "trades" under the tutelage of a master craftsperson, the AP English teacher. Through the purview of literature-study-as-craft, the AP English classroom becomes the master craftsperson's workshop; in essence, the AP English teacher assumes the role of master-craftsperson with student-apprentices - children-in the classroom-workshop.

\section{To Let-Learn}

Heidegger (1993) explores the teaching experience of the master cabinetmaker in connection with the learning experience of the apprentice: "Whether or not a cabinetmaker's apprentice, while he is learning, will come to respond to wood and wooden things depends obviously on the presence of some teacher who can teach the apprentice such matters" (p. 379). "The presence of some teacher," may be the dynamic presence of the AP English teacher in the classroom-workshop. Despite the prodigious 
talent, concerted effort, and tenacious commitment of many of our students, we still need to "teach." Heidegger (1993) states: "What teaching calls for is this: to let learn" (p. 380). What is called-for in letting-learn in the AP English classroom? Heidegger (1993) continues:

Indeed, the proper teacher lets nothing else be learned than-learning... If the relation between the teachers and the learners is genuine, therefore, there is never a place in it for the authority of the know-it-all or the authoritative sway of the official. (p. 380)

Heidegger's description of "the proper teacher" situates the AP English teacher in the Zone of Between. With the AP exam hovering throughout the school year, the AP English teacher has the answers in the form of answer keys to old AP tests, and the proverbial red pen to score essays according to College Board rubrics, and may find herself in the ill-fitting guise of know-it-all. Amanda makes a conscious decision to avoid the know-it-all role, as she gradually conditions students to facilitate meaningful discussions on the course reading:

I often do student-run discussions where I actually don't say much unless they really start to go off and have a misunderstanding...And at the beginning they always look at me when they're answering, even though I try to make it so they don't see me. But then eventually they just look at each other and they actually engage in conversations.

Amanda stays visible just long enough to become invisible to her students as they grow toward confident and independent literary discussions in class. The master-craftsperson is letting-learn as students take turns facilitating discussions, and class "leadership" as well as lively discussion become a more shared, collaborative, and student-centered experience.

Sennett (2008) offers what he describes as "a more satisfying definition of the workshop" (p. 54) that better addresses the tensions the AP English teachers' experience between letting-learn and knowing-it-all, between master and apprentice, and between teaching and testing: "A productive space in which people deal face-to-face with issues of authority" (p. 54). The most obvious authority issues in any high school classroom may arise between teenage students and their adult teachers; after all, the hallmark of adolescence may be understood as a breaking-from the established "norms," rules, and traditions of teachers-at-school and parents-at-home. The teacher-participants describe their students as "motivated academic types," "the best in the school," and "those who naturally do well at everything"; not one teacher-participant in the study mentioned defiance or discipline issues of any kind. Of course, there may be the occasional missed assignment, late paper, or tardy to class, but overall the authority issues between student and teacher are minimal in the AP English classroom.

Max van Manen (1991) reminds us that "pedagogical authority is the responsibility that the child grants to the adult...[to] ensure the child's well being and growth toward mature self-responsibility" (p. 70). As we in-habit authoritative stances in the AP English classroom, we still the "authoritative sway" (Heidegger, 1993, p. 380) in favor of a 
"pedagogical authority" (van Manen, 1991, p.70) that also encompasses what Kreisberg (1992) names as "curricular authority" (p. 211). Kreisberg (1992) writes:

Curricular authority would not reside in a list of facts generated by experts, but in the problems pursued by a community of learners and in the connections made between experience and knowledge.... In addition, the authority of expertise is based on a relationship of mutuality among members of a class, in which a teacher respects the voices and experience of her or his students, and the students in turn respect the teacher's. (p. 211)

Together, we pursue problems and make connections in our classroom communities. A common activity among the participants is collaborative multiple-choice practice, when students gather in small groups to share and defend their responses before the Scantrons are officially graded. Katherine describes:

They argue for their answers. You can hear amazing conversations when four of them think it's one answer, and the other one thinks it's the other answer, and that one person is right. It's nice that it's not always the teacher saying this is the right answer and this is why.

The mutual respect and connection-making that occur in AP English class emerge from Amanda's quest to be invisible during discussions to the lone ranger in a multiple choice group, daring to be different. At the same time, both Amanda and Katherine stress the importance of letting students learn to support their literary interpretations.

Amanda wonders, "how to convey to students that there is such a thing as a wrong answer when it comes to literature" and still maintain "a safe environment for delving into a text." Katherine's running joke with her classes is, "Well, you can't tell me the poem is about the Civil War," unless their "Civil War interpretation" works for every line of the poem. Amanda recently had a student whose shared misreading of Boswell led the whole class down the path of wrong answers. When Amanda pointed out the "common misreading," the outraged student insisted that his argument was as valid as anyone else's. The other students in the class began to assert their new interpretations with support from the text that they hadn't noticed before. The outraged student proclaimed that he was "sticking to [his] guns on this one," but was able to hear and to learn from the sharing of curricular authority in AP English class.

\section{Currere in Slow Craft Time}

Unless a student qualifies for special accommodations, the AP test is a timed test. Students, to do well on the AP English exam, need to read, think, and write quickly. The three essays that the students write during the testing period are, by their very nature, first drafts. Although we teach students that "writing is a process," and "writing is re-writing," on the AP English exams, writing is a first draft. Foster (1989) writes: "The written product - the text itself-is the course focus, not the composing process that generates text nor the reading process that re-creates it" (p. 6). The "composing process" may be impeded in our race for content coverage and high test scores. In our rush to the finish 
line - the in-class test practice session, the test itself, or getting from Beowulf to Beloved in eight short months - we may lose sight of the course we are running; the curriculum we are teaching.

The etymology of word curriculum begins with curricle, the noun meaning a racecourse or "a light two-wheeled carriage" (OED Online, 1989/2008). Derived from the Latin, currere, "a race chariot," or the race-course, the term currere evolved into an understanding of curriculum as a verb, stretching back to its etymological verb form, to run:

In Latin the word, currere, means running the race course-a verb. Mainstream understandings in the field of curriculum have traditionally reduced the word to its noun form, the track. In this context...mainstream educators forget that curriculum is an active process; it is not simply the lesson plan, the district guidebook, the standardized test, the goals and milestones, or the textbook. The curriculum...is a holistic life experience, the journey of becoming a self-aware subject capable of shaping his or her life path. (Kincheloe, 1998, pp. 129-130, emphasis added)

The nature of the "life path" we are shaping in the teaching of AP English is the curriculum we live and breathe in AP English. What Aoki (2005b) terms the "curriculumas-plan" and "curriculum-as-lived" (p. 161), is at-once a race to be run, the race-course or track on which our feet pound, as well as a journey to be experienced, reflected upon, and even savored along the way. It's a good thing we're "advanced" in advanced placement, as we are called upon to multitask: to be involved in many thoughts, actions, and activities simultaneously. We work with our students in class to read the questions, prompts, and passages rapidly but carefully, to underline and annotate as they go along, and to formulate a thesis or argument in record time. We may distribute poems photocopied in the context of test layout-with prompts, arrows, and multiple choice questions - but we also attempt to foster understanding and appreciation through questions and writing, both academic and personal. At the same time, timed test-taking is a skill that needs to be taught, learned, and practiced.

The timed nature of the AP English exams and our responsibility to train our students to work well under timed conditions present a powerful paradox for the master craftspeople in the classroom-workshop:

Craftsmen take pride most in skills that mature. This is why simple imitation is not a sustaining satisfaction; the skill has to evolve. The slowness of craft time serves as a source of satisfaction; practice beds in, making the skills one's own. Slow craft time also enables the work of reflection and imagination-which the push for quick results cannot. Mature means long; one takes lasting ownership of the skill. (Sennett, 2008, p. 295)

We take pride in "skills that mature" in the AP English classroom. After adhering to the steady rhythms of "slow craft time" during class, "slow craft time" may dissipate on AP Fridays and on exam day. All of the participants felt bound by time-constraints; one school year to guide students through a challenging and engaging college-level English course while preparing them for the exam never seems like enough time. The teacher- 
participants always feel rushed. They have their favorite books, projects, assignments, and approaches. Limiting pure test practice to "AP Fridays" helped a few of the teacherparticipants strike a better balance between what they wanted to do, and what they felt they had to do for test preparation. Still, they live in the tension. Amy shares:

There's just never enough time, and I try to push it. And I feel that I'm actually overworking, not necessarily overworking the kids, but they're not getting as much out of it. So I thought, you know, I'm going to just take it easy this year, and if I don't get everything done, like this semester, then I don't get everything done. Mostly, it's me because I want to get those creative projects in, too. And that's part of the problem because I feel they're important as well. That's what causes the conflict.

Amy's vow to not always "get everything done," privileges "slow craft time" over "the push for quick results" (Sennett, 2008, p. 295). Sennett (2008) writes, "The patience of the craftsman can thus be defined as: the temporary suspension of the desire for closure" (p. 221). The "desire for closure" in the AP English classroom may be the desire for high test scores on exam day. Our desire for a "practice [that] beds in, making the skills one's own," could be the desire that our students embody the living tenets of learning and loving literature in and beyond the AP English classroom, and on and beyond the College Board exam. As AP teachers, perhaps we are obligated to suspend the desire for "the practice [that] beds in" as we get closer to the test. Palmer (1998) reminds us: "I may not know how to solve [the tensions], but wrapping my life around them and trying to live out their resolution, I open myself to new possibilities and keep the tensions from tearing me apart" (p. 86).

\section{Cool Tools}

Palmer brings to mind my eleventh grade English teacher, Mr. Froysland, growing evermore frustrated with us - peering over his reading glasses, gripping the edges of his podium, chewing his flavor-worn Chiclet in double-time through the silence-after he asked about the symbolism of the turtle in Chapter Three of The Grapes of Wrath. The turtle-as-struggling-Joad-family seems so obvious to me now, but I have the right tools, and I know how to use them. Over years of experience as a student, and as a teacher, working with the tools of the trade, I have learned to translate figurative language into literal meaning, and express my interpretations to others through writing and speaking. I now provide my students with a set of tools and a set of skills with which to use those tools, in "slow craft time" (Sennett, 2008, p. 295) to better ensure their "lasting ownership" (p. 295).

Applebee (1996) would classify the tools of literary analysis in the AP English classroom as "cultural tools," which invite and enable students to "participate in a variety of socially constituted traditions of meaning-making that are valued in the cultures of which they are a part" (p. 9). Our teaching of AP English is a handing-down of what we know and love about approaching, understanding, and applying literature to our present work, our future work, and to our lives. But Applebee (1996) warns: 
Any conception of education that strips these tools of their contexts, or focuses on their past rather than on present relevance and future potential, will be debilitating for the individual and for the society as well. (p. 20)

In preparing our students for the College Board, we may run the risk of stripping the cultural tools of their context, relevance, or future potential for usefulness. Maybe the skills we practice with our students in preparation for a future test and its attendant college credit, debilitate our students, or diminish their future potential. Tina states: "I talk about the possibilities of a passage, but sometimes you feel like you're narrowing it down too much, instead of opening it up." Are we narrowing possibilities instead of expanding options for a life of literature-in-context? Applebee (1996) claims that educational researchers and students "note the discrepancy between grand goals of exploration and discovery, and the ways in which classroom interaction unfolds" (p. 21). This "discrepancy" might also be named as the Zone of Between in which the teacherconversants appear to dwell aright.

\section{The Proper Use for Several Tools}

In structuring meaning in the dwelling aright in the Zone of Between in AP English, I recall Gary Snyder's poem, "What Have I Learned." He writes of, "The moments/between hard pleasant tasks," which voice my experience of passing tools and skills to my students in the AP classroom:

What Have I Learned

What have I learned but

the proper use for several tools?

The moments

between hard pleasant tasks

To sit silent, drink wine, and think my own kind

of dry crusty thoughts.

- the first Calochortus flowers

and in all the land,

it's spring

I point them out:

the yellow petals, the golden hairs, to Gen.

Seeing in silence:

never the same twice, but when you get it right, you pass it on (Intrator \& Scribner, 2003, p. 105) 
The teacher-participants learned "the proper use of several tools," got it right, and passed it on-and continue to pass it on - to their students in the AP English classroomworkshop (minus the wine, of course). The experience of teachers passing it on to students in the AP English classroom includes what we see "in silence."

Katherine has come to know that she is working with her students in "the slowness of craft time" (Sennett, 2008, p. 295), and may not see "in silence" the immediate effects of her teachings:

I have come to peace with the idea that I'm laying the groundwork, that I think [the students] will have the skills when they are just taking three classes [in college] and they're sitting under a tree on some campus somewhere, and they're reading some book. They might actually have time to say, "Oh, this is really cool," and they'll have the tools to be able to read it.

James also honors the developmental stage at which his students arrive in his AP classroom. He worries sometimes that he's giving them literature that, as high school students, they may not be mature enough to grasp in a meaningful way. In giving them the tools they need to begin to understand literature that may be difficult, he articulates his conundrum by sharing a quotation from a friend: "When you dissect a frog, it's not a frog anymore":

There is a sense that we're depriving kids of literature. Actually, the thing I get more is I don't want to give kids something that they're not ready for. I don't want them to read something because they have to read it in class and ultimately steal the experience of it. I mean, what register do you have for this when you're 17 years old, but at the same time, isn't that literature's job? To bridge those gaps, to put us in totally different situations and make us see the universals? To relate to it in different ways? So I think, yes, I am afraid of ruining great literature for kids by making it clinical and dissecting the frog and so on.

But most of them are going to college to study marine biology and so on. They're smart kids, so really what they're doing is they're getting exposed to literature that they wouldn't otherwise. They're getting good guidance in it. Whatever I lose in overanalyzing something rather than just loving it, I think I gain in the fact that a lot of these kids get the chance to love literature through analyzing it.

James dwells in the tension between loving literature and "overanalyzing" it. He fears that he risks "steal[ing] the experience" of literature by giving students readings for which they may not be ready. With this concern at the forefront, James distributes the scalpels, cork trays, and frog carcasses, and with sensitivity to who and where his students are, guides them through the proper use of tools for literary frog dissection. He inhabits a let-learn approach with his students in the AP classroom, as he gives "good guidance" to exploring literature to which they may never have been exposed without the AP designation. His worry that he's stealing the experience of literature is assuaged by 
his realization that the future marine biologists in the room are receiving literary gifts they may never have unwrapped without his class. Though the participants' students may or may not see immediate results in terms of depth of understanding or high test scores, they have the experience with the literature and the tools of literary analysis available for their present coursework, their future test-taking, and their future lives as literary adults as they come of age in the AP English classroom-workshop.

\title{
Coming of Age in the AP English Workshop
}

\author{
What is a child? To see a child is \\ To see possibility, someone in \\ The process of becoming. (van Manen, 1991, p. 1)
}

At the special occasion gatherings of my extended family while I was growing up, we always had a separate children's table. The card table, usually set up in the living room, with a clear view of the dining room table of adults, was a matter of necessity. It wasn't that the children weren't welcome at the dining room table, there just wasn't enough room. We children sat around the card table on a mélange of folding chairs and other "seating," ottomans and step stools, culled from around the house. The children's table was as much a part of those early family traditions as the cut crystal bowls of Spanish peanuts and the relish tray of pickles and olives. From an early age, as amused as I was by my brother's and my cousins' concocted "cocktails" of every liquid and condiment on the table plus mashed potatoes, I was even more intrigued by the conversation in the dining room. I eavesdropped, and longed for the day when I, too, could join the conversation, or at least have a real chair from which I could hear better.

Joining the adult conversation, once it happened, was a non-event. I can't even remember making the transition from the card table to the dining room table, but the transition - like a bar mitzah or a quinceanera - is a time-honored rite of passage, deeply steeped in cultural traditions. A coming of age ceremony, with or without the big party, marks the end of childhood and the beginning of adulthood. But as the bar mitzvah haiku goes:

\section{Today I am a}

man. Tomorrow I return

to the seventh grade. (Bader, 1999, p. 75)

The bar mitzvah boy speaking in the haiku is in an in-between place. He is no more a man today, at his bar mitzvah ceremony, than he will be on Monday, when he returns to middle school. Under Jewish law, he is permitted to read from the Torah, and is expected to observe the commandments as an adult, but a seventh grader is still very much a child, hardly one to covet his neighbor's wife. High school juniors and seniors are much closer to adulthood than their seventh grade counterparts, but remain adolescents, especially in school, even if they take AP classes. Sudol (2008) writes: 
Some [AP] teachers try to propel students' growth by piling on extra work-more readings, more homework, more papers, more direct instruction, more grading. Ironically, these techniques actually make the AP course more like high school and less like college...I would like to suggest that a better way to equate the high school AP course to its college counterpart is to help students think and work independently and thereby make best use of the storehouse of common wisdom they are rapidly accumulating. (para. 4)

Stocking the "storehouse of common wisdom" eases the transition from the card table to the dining room table; from children's mashed potato "cocktails" to adult dinner conversation. Dwayne Huebner (1966/1999) states: "It is in conversation that the newness of each participant can come forth and the unconditioned can be revealed in new forms of gesture and language" (p. 112). A newness comes forth in the teaching of AP English, as new forms and gestures are revealed. Greenblatt (2008) writes:

The best teachers invite students to accompany us on a demanding journey, and then we help them to prepare and travel with us....An invitation is inclusive: we want them to join us (and generations before and after us) in a conversation about and exploration of literature. And if they don't know yet how to accept our invitation, then we need to show them how. It's not, however, always so easy to join the conversation. (para. 5)

As the conversations about literature have been going on for centuries, our students are latecomers (Greenblatt, 2008, para. 6). We do not so much bring them "up to speed," as we issue invitations to join the broadcast, already in progress. We, along with our students, "learn to take part in the traditions that encompasses the knowledge of the larger culture, and remake them as our own" (Applebee, 1996, p. 5). The process of remaking is also the process of innovating and cultivating, in and beyond the AP English classroom.

\section{Innovate and Cultivate}

In its botanical connotation, innovation refers to "the formation of a new shoot at the apex of a stem or branch," especially at the place where "the older parts [are] dying off behind" (OED Online, 1989/2008). We AP English teachers are not dropping dead at the moment, but our students are the new shoots who grow from our innovative pedagogical approaches. To cultivate means "to promote the growth of, to devote oneself to the advancement [emphasis added] of development of..." (OED Online, 1989/2008). As we promote our students' growth in the arts and crafts of literary analysis, self-expression, and standardized test taking, we meet them where they are, and devote ourselves to their advancement to the next place: the testing site, college, adulthood.

Several of us remember years back to when we were the burgeoning new shoots in someone else's classroom. Lisa's participation in this study brought to mind an essay that she wrote for admission to her master's in education program, after being in the work force for several years as a magazine writer, and then as a children's theater director and 
acting coach. She begins a journal entry for this study with an excerpt from her application essay:

In the beginning of my high school years, I lacked the confidence in myself to perform to my full potential. As a teenager, that lack of confidence plagued every aspect of my life until I ended up in the classroom of a very special teacher. This teacher was the first person to convince me that I was smart, and that my talents would take me wherever I wanted to go in life.

This particular teacher, Mr. H, instilled in Lisa a love of learning and a belief in self that carried her through college, graduate school, and her own teaching. Under his tutelage, she grew into a strong and confident young actress, writer, director, and scholar. Her newfound confidence translated to finding passions wherever she went as a college student and young adult, and helped her to pursue her interests in drama, creative writing, and literature. What she found in Mr. H's encouraging pedagogical style, she looked for and found in other instructors in college and graduate school: "I went to college and fully explored the lessons he taught me. I had witnessed the notable difference that comes from being taught by someone who actually cares and I was in awe." Lisa's articulation of "no longer [being] satisfied with ordinary means of learning" and "the power of learning in an open environment" laid the first building blocks of a personal teaching philosophy. She recalls after performing a skit in Mr. H's class, he suggested, "You should audition for the play." He sensed her interest in theater beyond the words on the page, saw her talent in an informal class skit, but it was his public encouragement that gave her the courage to take the important leap to the stage she would never have taken in high school without his specific personal support.

\section{Courage and Encouragement}

The etymological root of courage is Latin coraticum, or heart. An obsolete definition of courage is "the heart as the seat of feeling " and "what is in one's mind of thoughts, what one is thinking of or intending; intention, purpose, desire or inclination" (OED Online, 1989/2008). Mr. H, in knowing his students and in caring for them, gave them the gift of what he knew to be in their hearts; he uncovered and tapped into their desires. In short, Mr. H's teaching encourages students to "speak" their desires, which may have been unconscious or repressed (Ellsworth, 1997, p. 60-61):

Repression, then, doesn't mean that some illicit desire or knowledge has been stuffed away, somewhere deeper inside ourselves, where it exists unchanged but forgotten. Repression means that some indestructible, illicit knowledge of our desire has been changed into something symbolically unrecognizable to our conscious selves. (Ellsworth, 1997, pp. 60-61)

Mr. $\mathrm{H}$ recognizes desire in his students, and replaces what may be "symbolically unrecognizable...with other-usually more acceptable-symbols or signifiers" (Ellsworth, 1997, p. 61). As we teach for desire in the AP English classroom, we also help students change the unrecognizable into more acceptable symbols and signifiers. 
Though Mr. H was a social studies teacher, his teacherly ways still serve Lisa well as an English teacher.

Lisa recalls an opportunity she had to put Mr. H's lessons into practice with Ellen, a student she had in her first year of teaching AP Lit:

We were doing Jane Eyre and we talked in class about how Jane had this inherent self-worth, and how it was one of the things that I always admired about her. Ellen-varsity softball player, so smart, great grades, scholarships, you name it-comes to me after class asked if she could meet with me. When she came in later, she said: "You know in class how you were talking about Jane, how she had this, like, inherent self-worth? I was just wondering, how do you get that?"

But for me, and I explained this to her, it was about trying it on. Not like this ridiculous self-affirmation stuff, but it was about making it fit you, it was about finding what you were good at and what made you feel good about yourself and focusing on those things, rather than on the other things, and just learning to develop that...I think Mr. $\mathrm{H}$ was the catalyst for all of that in my life, and that's part of why I kind of came full circle back to teaching, and back to being here, that idea of confidence was something that I really wanted to give them.

Lisa's advice to Ellen that earning As does not necessarily translate to "inherent selfworth," and that learning is about finding what you're good at as well as what makes you feel good about yourself gives insight into Lisa's teaching "for possibility" and desire (Ellsworth, 1997, p. 172). Rather than equip her already straight-A, high-flying, highscoring student for another academic success as defined by standardized test scores, Lisa tends to her student's more pressing emotional needs while preparing her for the road ahead, equipping her with tools to endure and to thrive.

Confidence and passion go hand-in-hand in Lisa's teaching of AP Lit as she builds confidence, desire, and courage through literature-based activities in AP English class. Doll (2000) states: "One way to slow down, reflect, and feed the inner self is through engagement with fiction" ( $p$. xvii). By establishing pathways to personal connection through content, Lisa facilitated the relationship between Ellen and Jane Eyre. Jane Eyre's "inherent self-worth" that was central to Lisa's personal reading and public teaching of the novel, so touched her student, that the discussion extended beyond class and became the stuff of valuable life lesson for Ellen. Jane Eyre-as-role-model will stay with Ellen's student for a lifetime.

By creating a welcoming and safe space for her to voice her innermost fears, and by building the bridge that connects literature to growth and maturity, Lisa hearkens back to the lessons she learned from $\mathrm{Mr}$. $\mathrm{H}$ and puts them into practice as an empathetic teacher in her own right. To hearken derives from the verb to hear and is "supported by the analogy of heart and hearth" (OED Online, 1989/2008). Lisa's heart-felt reading of Jane Eyre transforms her student, Ellen, in the safe hearth of their classroom-home.

Another term for hearkening is to "give ear" (OED Online, 1989/2008), which leads to an understanding of the verb to hear as an embodiment of the sense. To really hear or 
listen to someone is a bodily experience that engages ears and heart. Heidegger (1953/1996) writes:

Only when the existential possibility of discourse and hearing are given, can someone hearken. He who "cannot hear" and "must feel" can perhaps hearken very well precisely for this reason. Just listening around is a privation of the hearing that understands. Discourse and hearing are grounded in understanding. Understanding comes neither from a lot of talking nor from busy listening around. Only he who already understands is able to listen. (p. 154)

"The hearing that understands" in the teaching AP English is Lisa's hearing and understanding Ellen vis a vis Jane Eyre, much as $\mathrm{Mr}$. $\mathrm{H}$ heard and understood Lisa as a young student searching for self worth vis a vis classroom skits. Levin (1989) names hearkening as "a mode of perceptiveness that we can only achieve by cultivating our capacity for feeling and listening" (p. 218). What happens to our "feeling and listening" when we clock multiple choice test practice or grade our students' in-class essays on the 1-9 College Board rubric? As we recognize desire, ignite passion, and bolster confidence, what happens to our capacity to hearken come test time?

\section{Passion Building}

E.E. Cummings writes in his poem, "You Shall Above All Things": "I'd rather learn from one bird how to sing/than teach ten thousand stars how not to dance" (in Intrator \& Scribner, 2003, p. 143). In listening to and hearing her student's concerns about selfworth, then offering stories and insights from her own life experience, Lisa learns from her student "how to sing" - how to use her own life stories, with a little help from Charlotte Bronte, to teach and reassure students. Lisa's story about Ellen and reminiscences about $\mathrm{Mr}$. $\mathrm{H}$, bring to the surface why and how she became a teacher in the first place.

When Lisa reflects on her graduate school application essay from the position of an experienced teacher, she writes: "It's funny how much of what I wrote six years ago that I thought was 'fluff' is actually true." In finding the truth in her earliest forays into the teaching realm, she also revises, in the sense of seeing anew, what she wrote as a preservice teacher: "It's not the confidence building in my students that keeps me here, despite my initial intentions, but rather the passion building, the critical thinking, and even the rising to the challenge of the College Board's test each year." The College Board's AP Lit exam is included in Lisa's list of what keeps her engaged in teaching AP English, as she considers its challenges to be an important part of not only the "confidence building" aspect of her work, but also the "passion building" that has come to define her mission in the AP classroom.

We may experience standardized tests as confidence-builders, when students practice and put forth a certain type of effort that endures and improves over time, but tests can also be passion-builders. The concept of the AP English exams as passion builders takes some getting used to. Ellsworth (1997) writes: 
The bottom line for assessment purposes is for a student to get it, comprehend it, be "conscious" of it; even if she didn't want to get it, didn't enjoy getting it, or does not intend to use it... (p. 46)

The AP English exams take "the bottom line" to new heights. Lisa uses the lofty "rising to the challenge" to name the experience of preparing students for the AP Lit. exam. Lisa's experience with Ellen, and other students, puts faces on the often faceless endeavor of standardized testing. Teacher-participant Amy says of her students: "I like to see when they grow, and realize, 'Wow, I can do this." 'Being present to witness growth, Amy and the other participants transform the exam into a personalized, healthy challenge for the students. Aoki (2005a) writes:

In the rather disembodied language world of the $\mathrm{C}$ [Curriculum] \& I [Instruction and Implementation] landscape, the others-teachers and students - are only implied in words like "implementation," "instruction," and "assessment." ...Further, these others become faceless and thus are reducible to some kind of sameness. This becomes discernible when assessment time comes, when all students are subjected to districtwide, provincewide, or even nationwide tests. (p. 299)

Lisa, and the other teacher-participants, add not only faces, but also whole bodies to the "disembodied language world" of traditional curriculum, instruction/implementation, and assessment. The teachers stand between the students and the test as they defy the sameness that "becomes discernible...when all students are subjected" to the standardized AP English exam in the spring. Tina emphatically states, "The College Board doesn't know my kids and where they are," but her knowledge of her students, and where and who they are, ignite and fuel passion that keeps her teaching "for possibility" (Ellsworth, 1997, p. 172), amidst the tensionality in the AP English classroom. Aoki (2005b) reminds us "that to be alive is to live in tension":

It is the tensionality that allows good thoughts and actions to arise when properly tensioned chords are struck, and that tensionless strings are not only unable to give voice to songs, but also unable to allow a song to be sung. (p. 162)

Though Lisa learns from "the one bird," Ellen, "how to sing," she fears that she may be, at the same time, teaching "ten thousand stars how not to dance." Six years post-Ellen in her teaching career, Lisa finds herself dwelling in a tension-filled locale between teaching and testing, and wonders what songs of passion and compassion emanate from the ever tightening strings.

\section{Compassion Building}

Lisa's entry does not stop with the naming of passion building as an integral part of her teaching. She continues to question the test's presence, and the feedback students give her, concerning their performance as determined by the College Board's one-through-five exam grading scale: 
I never really thought it would mean more for a student to send me an email thanking me for pushing him and helping him earn a 4 on the AP Lit exam than an email about how I was his favorite teacher and made his day easier, but it does. Maybe this means that test has warped me, too, or maybe I'm just not as nice or compassionate as I thought I was?

To be compassionate in the AP English classroom is to experience passion together, as well as to suffer together, in a community of learners who are also test takers. Lisa's appreciation for her student's email, but her concern that she, too, may be "warped" by the emphasis on test scores, illuminates her experience of the tension between teaching in the sense that Mr. H taught her, and teaching in the current climate of hallowed "student achievement," where "effective" teaching is determined by passing scores-fours or fives - on AP exams. Six years into her teaching career, she fears that she may be losing the lessons learned from Mr. $\mathrm{H}$, lessons she was closer to, in time and in practice, as a first year teacher with student Ellen, than she is now.

Lisa attempts to reconcile what she experiences as "a divided life" (Palmer, 1998, p. 167) in her teaching of AP English. Palmer (1998) writes:

We inhabit institutional settings, including school...because they harbor opportunities that we value. But the claims those institutions make on us are sometimes at odds with our hearts...That tension can be creative, up to a point. It becomes pathological when the heart becomes a wholly owned subsidiary of the organization, when we internalize organizational logic and allow it to overwhelm the logic of our own lives. (p. 167)

An "organizational logic" may be overwhelming Lisa's life logic. In coming into her own as a teacher, Lisa has incorporated, embodied, and adapted to the requirements and reality of teaching AP. She has reconciled teaching to students and teaching to tests, at the same time. She, along with the other teacher-participants, make AP teaching and testing their own in their daily interactions with students, texts, and tests. To avoid what Palmer terms the pathology of the heart, Lisa and the other teacher-participants "indwell between two horizons" (Aoki, 2005b, p. 161); the tensionality they experience between teaching and testing, is also the tensionality between subject and object, self and other. The outside emphasis on the external assessment of the College Board exam invites a fragmentation of which the teachers are aware, while at-once resisting and embracing the inherent contradictions. Jardine, LaGrange, \& Everest (2003) write: "We are all living out a deep cultural logic of fragmentation that distracts attention" (p. 204). Tina shares:

I think when you look at a kid, and you're like, "You, I'm going to bring your scores up"-you're not really focusing on the kid and on what he or she needs. You're focusing on how to get them to a test score where someone else has said you need to get them. So all of a sudden it's just all about testing, testing, testing, testing. Even sometimes when a kid has a more creative approach to something, you almost feel like, "You can't do that, because they want this." It kills some of the enthusiasm and creativity. 


\section{Borenzweig}

The rise of fragmentation "for the sake of our own efficiency" (Jardine, Clifford, and Friesen 2003, p. 8), and the impending death of enthusiasm and creativity to which Tina refers, spur the teachers to practical action. Although the teachers in the study are not yet familiar with the work of Ted Aoki (2005b), they seem to practice his wisdom: "We must recognize the flight from the meaning and turn back again to an understanding of our own being as teachers" (p. 164).

Turning back to her understanding of her own being as teacher, Lisa reflects upon and responds to a set of course evaluations from the end of first semester. She writes:

In the sea of "Mrs. Schwartz rocks," and "Best English class I've ever had!" and "Learned more in this class than in all the rest of high school," and "Good luck on your baby," was the meanest student comment I've received in six years of teaching: "I also believe the class would be better if Mrs. Schwartz appeared more than just a teacher but a person who cares about the lives of her individual students (even if she does not, it would be nice if she pretended she did.)"

Though Lisa is well aware that she will never be everyone's favorite teacher, this comment is an anomaly for her, and she takes it to heart. As the evaluations are completed anonymously online, she has no way of knowing who wrote it, but is both baffled and bothered by the comment:

So I read it and I wonder, have I become so remote in my teaching that somehow this student misread me so grossly? Does teaching AP and wanting rigor in the classroom come at the cost of my purpose of becoming a teacher in the first place: to boost the confidence of my students, to ignite passion in their hearts and minds? The fact that he called me "just a teacher" really hurts, too. This student tells me, or the me he sees, and "that me" is nothing like the teacher or the person I am. I am left to wonder if he misjudged me or if I have failed him and myself this semester.

Akin to Ellen, Lisa's student who questioned her own self worth after reading Jane Eyre, Lisa's self worth as a teacher is called into question when she considers how hurt she was by this student's comments. Lisa's sense of self-worth faces a test of her anonymous student's making. Lisa's self-doubt may stem, in part, from the AP testing milieu. Greeting students by name at the door, engaging them in class, working with them beyond the school day, and sponsoring several extracurricular activities, are somehow not enough to reach every student and to show everyone that she cares about them as individuals, both in and beyond the classroom, and on and beyond the AP Lit exam in May.

She doesn't expect to maintain 100\% approval ratings, but the characterization of her as "just a teacher" takes her aback. Her wondering, "if that drive for performance made me pay more attention to what I was getting out of them, than what I was putting in" brings to mind the words of Ellsworth (1997): "The good teacher is the one who gives what s/he doesn't have..." (p. 173). Lisa's dissatisfied student wants what Lisa is not giving him. He seems to expect of her something that she does not have to give, that is 
not hers to give. Her concern is that perhaps this student is more astute and honest than the others, picking up on her insecurity in the teaching-testing tension that the other students either did not notice, or did not dare mention to her. In the tensionality between "the divided life" (Palmer, 1998, p. 167) and "dwelling aright" in the Zone of Between (Aoki, 2005b, p. 164), Lisa wonders if putting in "so much of [her]self" still is not quite enough.

\section{Is This Enough?}

Lisa, pregnant with her first child, asks herself the same question she is likely to ask herself as a parent many times in the coming years: Is this enough? She would be wise to heed the words of Bruno Bettelheim (1987): "But it is quite possible to be a good enough parent - that is, a parent who raises his child well" (p. xi). What is "good enough" in the teaching of AP English? Raising our children well may also mean raising their test scores. James considers these questions and others, in a journal entry:

What really sets AP Lit apart from an Honors English class? I can teach students a piece of literature. I can stimulate great class discussions. I can construct challenging and engaging assignments, but is that it? I am a very self-critical person; I am always pushing myself to get better. In teaching AP, I find myself constantly wondering, "Is this enough?"

James' question, "Is this enough?" brings to mind van Manen's (2003) fundamental pedagogical question: "Did I do the right thing?" (p. 147). It is this very questioning, selfdoubt, and constant striving that define aspects of the pedagogical nature of the AP English teacher-participants. Van Manen (2003) writes: "Pedagogy is this questioning, this doubting" (p. 147). James continues his musings after a day in the classroom with his AP Lit students:

Right now I am teaching The Age of Innocence. I can teach this novel on a number of levels. We can approach it from different critical perspectives, we can look at Wharton's life, the socioeconomic context of her writing, we can question whether Wharton's approach actually undercuts feminism, after all. But in the midst of all this character development and motif-finding, and structural analysis, I still ask myself: "Shouldn't I teach principles of interpretation, not what is the symbolism in Chapter 18? I often feel that I am stopping short of the real point. These things trouble me.

In his teaching of AP Lit, James often has the sense that he's "stopping short of the real point." What is the real point in teaching AP English? Does the "real point" always translate to points earned in a timed setting in the form of test scores? James' journal entry's ending, "These things trouble me," names in part what sets him and his AP colleagues apart from other teachers. Other teachers are troubled or unsettled by what transpires in their classrooms, but perhaps the constant presence and pressure of the test, with the simultaneous expectations from the students that we prepare them for college in 
a college-like English course in high school, set teachers on a never-ending path of wondering, doubting, refining, reflecting, and revising.

\section{Rigor and Vigor}

Maxine Greene (1995) writes: "Where standards and rigor are concerned, it is profoundly important to communicate to young people the connection between the discipline or the effort they exert and the possibilities of vision" (p. 182). As we seek real points and rigor in our teaching, we try to help students make the necessary connections between their efforts and "the possibilities of vision." James shares: "It's a rigorous course. I worry sometimes that it is not rigorous enough. I worry sometimes that this is a glorified honors course. But, obviously, each year I try to push myself to make sure I'm maintaining, if not increasing, my rigor."

The etymological root of the Latin rigor is numbness or stiffness (OED Online, 1989/2007). Van Manen (2003) draws a distinction between the sense of "rigor" in traditional scientific research, and the notion of rigor in phenomenology. Our understanding of "hard data" (p. 17) in the scientific realm refers to knowledge that is "hard-nosed, strict, and uncompromised by 'subjective' and qualitative distinctions" (p. 17). Van Manen (2003) contrasts: "A strong and rigorous human science text distinguishes itself by its courage and resolve to stand up for the uniqueness and significance of the notion to which it has dedicated itself" (p. 18). We have dedicated ourselves and our resolve to "uniqueness and significance" in AP English. In our quest for higher numbers in AP English, we risk numbing our pedagogy, our relationship with our students, ourselves. Perhaps we become stiff with inflexibility as we conform to the constraints of the College Board exams. We are familiar with the term, rigor mortis, "the stiffness of the body following upon death" (OED Online, 1989/2007). What dies and grows cold when we teach to the test instead of teaching to the students? What happens to vigor in our quest for rigor? Educator Dennis Littky (2004) writes:

Most people look for rigor in the course syllabus or in the number of hours students spend studying for a test. Sadly, some see rigor when a large number of students can't meet the standard and don't pass. But the rigor that I am talking about is the same rigor Mihaly Csikszentmihalyi describes when he says we can "do no better than to call for...the opportunity for young people to experience intense concentration in any activity that requires skill and discipline..." (p. 116)

The "most people" to whom Littky refers would find "rigor" in the AP English course syllabi and would name as "rigorous" the sheer quantity of time students spend preparing for the test. The call for rigor in the AP English classroom might also be understood as the call for the intense concentration of the artist-craftsperson in the literary classroomworkshop.

Katherine reminds me that AP exams, unlike state or county exams, are "optional high stakes tests." Even in schools where students are required to take the College Board exam if they are enrolled in an AP course, the students still choose (or their parents choose for them) to register for the course. The exam becomes a vehicle-of-choice not only for confidence and passion building, but also for empowerment, as students learn to 
use the tools of the literary trades. Some students may even begin to master the tools of the literary trades in AP class, as they hone close reading, critical thinking, eloquent speaking, and elegant writing skills.

Despite the standardization of the College Board exams, students can find and use their own voices in the AP English classroom, and on the AP English exams. Veteran AP English teacher Harvard Knowles (2008) writes:

AP indicates a belief in the depth, the complexity, and especially the power of language to speak to the experience of us all. [Students] should emerge...with the knowledge that it is their imagination, effort, and commitment that breathe life into words, for they should know that it is not just the writer's words that make literature; it is, as well, the reader's imagination. (para. 2)

Fostering the imagination and encouraging students to use their own breaths to enliven texts are not the common notions attributed to the realm of high-stakes standardized testing. But borrowing the slogan from parent-activist Susan Harman's T-shirt: "High stakes are for tomatoes" (in Schrag, 2000, para. 9), the AP English experience is rigorous in its invigorating approach to literature, to students, and to personal expression. We would agree that children are not tomatoes, but then again, garden stakes support plants as they reach for the sun, and grow to their full potential. Perhaps a bit severe in their appearance, tomato plants grasped by stakes still yield, or let go, the juiciest and most mature harvest.

\section{Grasping and Letting Go}

Sennett (2008) writes, "To say that we 'grasp something' implies that we reach for it" (p. 153). In grasping, we anticipate the holding - a cup, a pencil, a hand - before we actually make physical contact. "Mentally," Sennett (2008) continues, "we 'grasp something' when we understand the concept" (p. 154). Phenomenologically, in our quest to understand and name aspects of the essence of the lived experience, we practice "reflective grasping" (van Manen, 2003, p. 32) and illuminate what grasps, or presents itself, to us. In a similar vein, in the teaching of AP English, we want our students to grasp for-in the physical sense of reaching-with-readiness - what's to come, to anticipate, and also to grasp, and be grasped by, a sense of deep understanding. On test day, we want our students to wrap their fingers around a number-two pencil, while wrapping their heads around the knowledge required to fill in the correct bubbles on the Scantron forms. We want our students to grip their trusted pens with confidence and write, in the form of three essays in two hours, the ideas that they hold in their heads and hearts. But Sennett (2008) warns: "There is a problem about grips... This is how to let go" (p. 151).

In our experience as teachers-as-master-craftspeople and teachers-as-parents, we "grasp" our apprentice-children only to have to let them go in a relatively short period of time. Van Manen (1991) writes: 
A teacher's affection for a pupil, like a parent's affection for a child, is premised to a large extent on the value of becoming and growth...A parent, like a teacher, loves a child as a person who is essentially in the process of becoming. (p. 67)

And what of the children who sit in our classrooms now? Each child's meaning for me, and for the conversants, "lies in the present" (van Manen, 1991, p. 67), yet at same time, in the future. All teachers may wish for their students to grow to be lifelong readers and independent thinkers, but AP teachers have the multiple aspirations of wanting their students to pass the AP English exam, be exempt from introductory college English, and also grow to be lifelong readers and independent thinkers. Participant Amanda states, "My goal for my students is to be well-read, well-spoken, and ready for college." The multiple aspirations are not mutually exclusive, but is it necessary to earn college credit to be "ready for college" before setting foot on a university campus? Tina posits:

My students will get to college and they can have the college experience there. They can grow and they can learn and it can be fun. They'll get college experience later on. I don't think it's necessary that they get the college experience in high school.

Is it even possible to get the "college experience" in high school? Inhabiting the high school AP English classroom with our students for a year invites them to share in our frustrations and celebrations of dwelling aright in the many Zones of Between.

Among the skills we model for our students is living in the tensions: between art and craft, teaching and testing, learning and testing-taking, high school and college, and childhood and adulthood. No matter how ritualized our AP Fridays or how high our students score on the AP exams, we journey with our students on the path to adulthood, as we are all in the process of becoming. Van Manen (1991) writes of a student:

Obviously I do not know who or what this child will become; I cannot tell the future...I notice signs of a new maturity: a personal way of talking, a new pleasant confidence or a disarming shyness, a surprising critical judgment, a hard-won ability, an unsuspected talent, a certain way of walking, gesturing, or moving the body - it is in many little things that we see a child learn and grow up. (p. 67)

What are the "many little things" we see in our AP English classrooms? What art/craft, teaching/testing, learning/loving inform our experience? Re-calling James' language, what is the "real point"? Greene (1995) writes:

As we ponder educational purposes, we might take into account the possibility that the main point of education (in the context of a lived life) is to enable a human being to become increasingly mindful with regard to his or her lived situation - and its untapped possibilities. (p. 182) 
As we seek to tap untapped possibilities, in ourselves and our students, we also let-learn to let-go of the prescribed and the fixed, relying on our experience, innovation, and intuition. Sennett (2008) writes:

Intuition begins with the sense that what isn't yet could be. How do we sense this? In technical craftsmanship, the sense of possibility is grounded in feeling frustrated by a tool's limits or provoked by its untested [emphasis added] possibilities. (pp. 209-210)

What are the "untested possibilities" in the teaching of AP English? The philosopher Ludwig Wittgenstein, when designing a house for his sister in Vienna is purported to have said: "I am not interested in erecting a building, but in...presenting to myself the foundations of all possible buildings" (in Sennett, 2008, p. 254). What "foundations of all possible buildings" might we be constructing with our students? As we teach "for possibility" (Ellsworth, 1997, p. 172) in the AP English classroom-tapped and untapped, tested and untested-we hold our students' presents and futures in our hands, and we rely on intuition, experience, and pedagogical tact to know when to grasp, when to-be grasped, and when to let-go. As teachers we may explore the future we cannot tell, as well as the hopes we glean from our daily passionate work with our studentapprentices in the AP English classroom-workshop, and what we may build on the foundations of those hopes and those passions.

\section{References}

Aoki, T. (2005a). Humiliating the Cartesian ego. In W. Pinar \& R. Irwin (Eds.), Curriculum in a new key: The collected works of Ted Aoki (pp. 291-301). Mahwah, NJ: Lawrence Erlbaum. (Original work published 1993)

Aoki, T. (2005b). Teaching as in-dwelling between two curriculum worlds. In W. Pinar \& R. Irwin (Eds.), Curriculum in a new key: The collected works of Ted Aoki (pp. 159-165). Mahwah, NJ: Lawrence Erlbaum. (Original work published 1986)

Applebee, A.N. (1996). Curriculum as conversation: Transforming traditions of teaching and learning. Chicago: University of Chicago Press.

Bader, D. M. (1999). Haikus for Jews. New York: Harmony.

Bettelheim, B. (1987). A good enough parent. New York: Vintage.

College Board. (1995). 1994 AP English literature and composition: Free-response scoring guide with multiple choice section. Princeton: Educational Testing Service.

Doll, M.A. (2000). Like letters in running water: A mythopoetics of curriculum. Mahwah, NJ: Lawrence Erlbaum.

Ellsworth, E. (1997). Teaching positions. New York: Teachers College Press. 


\section{Borenzweig}

Foster, D. (1989). The theory of AP English: A critique. In G.A. Olson, E. Metzger, \& E. Ashton-Jones (Eds.), Advanced placement English: Theory, politics, and pedagogy (pp. 3-24). Portsmouth, NH: Boynton/Cook.

Greenblatt, E. (2008). The art of teaching AP literature: An introduction. Retrieved from http://apcentral.collegeboard.com

Greene, M. (1995). Releasing the imagination: Essays on education, the arts, and social change. San Francisco: Jossey-Bass.

Heard, G. (1995). Writing toward home. Portsmouth, NH: Heinemann.

Heidegger, M. (1993). What calls for thinking? In D.F. Krell (Ed.), Martin Heidegger: Basic writings (pp. 369-391). New York: Harper \& Row.

Heidegger, M. (1996). Being and time (J. Stambaugh, Trans.). Albany: State University of New York Press. (Original work published 1953)

Huebner, D. E. (1999). Curricular language and classroom meanings. In V. Hillis (Ed.), The lure of the transcendent: Collected Essays by Dwayne E. Huebner (pp. 101-117). Mahwah, NJ: Lawrence Erlbaum. (Original work published 1966)

Intrator, S. M., \& Scribner, M. (Eds.). (2003). Teaching with fire: Poetry that sustains the courage to teach. San Francisco: Jossey-Bass.

Jardine, D., Clifford, P., \& Friesen, S. (2003). Introduction: An interpretive reading of "back to basics." Back to the basics of teaching and learning: Thinking the world together (pp. 1-39). Mahwah, NJ: Lawrence Erlbaum.

Jardine, D., LaGrange, A., \& Everest, B. (2003). "In these shoes is the call of the earth": Meditations on curriculum integration, conceptual violence, and the ecologies of community and place. Back to the basics of teaching and learning: Thinking the world together (pp. 197-205). Mahwah, NJ: Lawrence Erlbaum.

Kincheloe, J. (1998). Pinar's currere and identity in hyperreality. In W.F. Pinar (Ed.), Curriculum: Toward new identities (pp. 129-142). New York: Garland.

Knowles, H. (2008). Nurturing the reader's imagination. Retrieved from http://apcentral.collegeboard.com

Kreisberg, S. (1992). Transforming power: Domination, empowerment, and education. Albany: State University Press of New York.

Levin, D. (1989). The listening self: Personal growth, social change, and the closure of metaphysics. New York: Routledge.

Littky, D. (2004). The big picture: Education is everyone's business. Alexandria, VA: ASCD. 
Meier, D. (2002). In schools we trust: Creating communities of learning in an era of testing and standardization. Boston: Beacon Press.

Oxford English Dictionary Online (1989/2008). Retrieved from www.oed.com

Palmer, P. (1998). The courage to teach. San Francisco: Jossey-Bass.

Schrag, P. (2000, August). High stakes are for tomatoes. The Atlantic. Retrieved from http://www.theatlantic.com/issues/2000/08/schrag.htm

Sennett, R. (2008). The craftsman. New Haven, CT: Yale University Press.

Sudol, R. (2008). The world is their subject: AP English language. Retrieved from http://apcentral.collegeboard.com

van Manen, M. (1991). The tact of teaching: The meaning of pedagogical thoughtfulness. Albany: State University of New York Press.

van Manen, M. (2003). Researching lived experience: Human science for an action sensitive pedagogy. Albany: State University of New York Press. 